\title{
Molecular cloning of equine $17 \beta$-hydroxysteroid dehydrogenase type 1 and its downregulation during follicular luteinization in vivo
}

\author{
Kristy A Brown, Khampoune Sayasith, Nadine Bouchard, Jacques G Lussier and Jean Sirois
}

Faculté de Médecine Vétérinaire, Centre de Recherche en Reproduction Animale, Université de Montréal, 3200 Sicotte, Saint-Hyacinthe, Québec, Canada J2S 7C6

(Requests for offprints should be addressed to J Sirois; Email: jean.sirois@ umontreal.ca)

\begin{abstract}
The type 1 form of $17 \beta$-hydroxysteroid dehydrogenase (17ßHSD1) was the first isoform to be identified and is capable of converting estrone to $17 \beta$-estradiol. This study was aimed at characterizing the molecular structure of the equine 17\%HSD1 gene and cDNA, as well as its molecular regulation during human chorionic gonadotropin (hCG)-induced follicular luteinization/ovulation in vivo. The equine $17 \beta H S D 1$ gene was cloned from an equine genomic library and shown to have a conserved genomic structure composed of six exons. Its cDNA sequence was also identified and coded for a 308 amino acid protein, $72 \cdot 1-74 \cdot 5 \%$ homologous to other mammalian orthologs. RT-PCR/Southern blot analyses were performed to study the regulation of the $17 \beta \mathrm{HSD} 1$ transcript in equine preovulatory follicles isolated between 0 and $39 \mathrm{~h}$ after hCG treatment. Results demonstrated the presence of high $17 \beta \mathrm{HSD} 1 \mathrm{mRNA}$ expression prior to hCG treatment with a marked decrease observed $12 \mathrm{~h}$ after hCG $(P<0.05)$. Analyses on isolated preparations of granulosa and theca interna cells identified the granulosa cell layer as the site of $17 \beta \mathrm{HSD} 1$ transcript expression and downregulation $(P<0 \cdot 05)$. A $1412 \mathrm{bp}$ fragment of the equine $17 \beta \mathrm{HSD} 1$ proximal promoter was sequenced and shown to contain many putative transcription factor binding sites. Electromobility shift assays (EMSA) using a fragment of the proximal promoter $(-230 /-30)$ and nuclear extracts prepared from granulosa cells isolated prior to hCG $(0 \mathrm{~h}$ post-hCG) revealed the presence of a major complex, and results from competition assays suggest that steroidogenic factor-1 (SF-1), NF $\mathrm{B}, \mathrm{GATA}$, and Sp1 cis-elements are involved. Supershift assays using an antibody against the $\mathrm{p} 65$ subunit of $\mathrm{NF} \kappa \mathrm{B}$ led to the displacement of the binding nuclear proteins to the DNA probe, whereas the use of an anti-equine SF-1 antibody demonstrated the clear formation of a DNA-protein-antibody complex, confirming the potential role of these transcription factors in EMSA results. Interestingly, a notable decrease in DNA binding was observed when granulosa cell nuclear extracts isolated $30 \mathrm{~h}$ post-hCG were used, which paralleled the decrease in $17 \beta \mathrm{HSD} 1$ transcript after hCG treatment. Thus, this study is the first to report the gonadotropin-dependent downregulation of $17 \beta \mathrm{HSD} 1$ transcript expression in a monoovulatory species, the presence and regulation of protein/DNA interactions in the proximal region of the $17 \beta \mathrm{HSD} 1$ promoter during gonadotropin treatment, and the characterization of the primary structure of equine $17 \beta \mathrm{HSD} 1 \mathrm{cDNA}$ and gene.
\end{abstract}

Journal of Molecular Endocrinology (2007) 38, 67-78

\section{Introduction}

The biosynthesis of ovarian steroid hormones requires a complex enzymatic cascade that ultimately involves the enzyme, 17 $\beta$-hydroxysteroid dehydrogenase $(17 \beta \mathrm{HSD})$, in the production of both androgen and estrogen secretory products. Twelve types of $17 \beta$ HSDs have thus far been described, and numbered in the order in which their DNA sequences were determined. They are all members of the short-chain dehydrogenase/reductase superfamily, except for type 5, which belongs to the aldo-keto reductase superfamily (Adamski \& Jakob 2001, Baker 2001, Luu-The 2001, Luu-The et al. 2005). These 17ßHSDs catalyze the interconversion between less active 17-ketosteroids (i.e. low receptor affinity) and more active $17 \beta$-hydroxysteroids (i.e. high receptor affinity) such as estrone and 17ß-estradiol respectively (Penning 1997, Peltoketo et al. 1999). The occurrence of different substrate specificities, cofactor preference, subcellular localizations, and tissue distributions allows 17ßHSDs to dictate the biological potency of androgens and estrogens in mammals.

Type $117 \beta$ HSD (17ßHSD1) was the first $17 \beta$ HSD to be characterized. Its cDNA was first cloned from human placenta and was shown to encode a cytosolic protein of 327 amino acids (Peltoketo et al. 1988, Luu The et al. 1989). It has been shown to preferentially catalyze the reduction of estrone to $17 \beta$-estradiol using $\mathrm{NADP}(\mathrm{H})$ as a cofactor in humans (Dumont et al. 1992, Lin et al. 1992), whereas its substrate specificity in rodents is broader as it includes androstenedione (Nokelainen et al. 1996, Mustonen et al. 1997). Tissue distribution analyses revealed $17 \beta \mathrm{HSD} 1$ transcript expression in the ovary, 
placenta, breast, endometrium, prostate, skin, and adipose tissue (Peltoketo et al. 1988, Dumont et al. 1992).

In mammals, the preovulatory surge in luteinizing hormone is responsible for the process of follicular luteinization, which is accompanied by dramatic changes in follicular steroidogenesis, including the decreased biosynthesis of 17 $\beta$-estradiol (Fortune 1994, Zeleznik 1994, Murphy 2000). The marked decrease in expression of cytochrome $\mathrm{P} 450$ enzymes, such as $\mathrm{P} 450$ aromatase (CYP19A1) and P450 17 $\alpha$-hydroxylase/C1720 lyase (CYP17A1), has been used to explain this loss in $17 \beta$-estradiol biosynthetic capacity (Fortune 1994, Richards 1994, Liu et al. 1999). To date, no attempts have been made to elucidate the regulation of enzymes required for the activation of these estrogens, such as $17 \beta \mathrm{HSD} 1$, during the luteinization process in monoovulatory species. The present study uses the equine preovulatory follicle as a model to investigate the regulation of $17 \beta \mathrm{HSD} 1$ during gonadotropin-induced ovulation/luteinization. The specific objectives were to clone the equine 17ßHSD1 gene and cDNA, and determine the regulation of its mRNA in preovulatory follicles following human chorionic gonadotropin (hCG) treatment, as well as begin characterizing interactions at the level of the $17 \beta \mathrm{HSD} 1$ promoter.

\section{Materials and methods}

\section{Materials}

The QuickHyb hybridization solution and the equine genomic library were obtained from Stratagene Cloning Systems (LaJolla, CA, USA); $\left[\alpha^{32} \mathrm{P}\right] \mathrm{dCTP}$ was purchased from Perkin-Elmer Canada, Inc. (Woodbridge, Ontario, Canada); the Prime-a-Gene labeling system and pGEM-T Easy Vector System I were obtained from Promega Corp.; the Expand High Fidelity DNA polymerase was purchased from Roche Diagnostics (Laval, Québec, Canada); the plasmid pcDNA3·1, SuperScript II reverse transcriptase, TRIzol total RNA isolation reagent, $1 \mathrm{~kb}$ DNA ladder, 5'-rapid amplification of cDNA ends (RACE) system (version 2.0), and synthetic oligonucleotides were obtained from Invitrogen Life Technologies; the Qiagen OneStep RT-PCR System was purchased from Qiagen, Inc.; Biotrans nylon membranes $(0 \cdot 2 \mu \mathrm{m})$ were obtained from ICN Pharmaceuticals, Inc. (Montréal, Québec, Canada); Bio-Rad Protein Assay and all electrophoretic reagents were obtained from Bio-Rad Laboratories; hCG was purchased from The Butler Co. (Columbus, OH, USA); and poly $(\mathrm{dI} / \mathrm{dC})$ was obtained from Amersham Pharmacia Biotech. Polyclonal antibodies against p65 nuclear factor $(\mathrm{NF}) \kappa \mathrm{B}$ (catalog number sc-372X), p50 NFкB (sc-7178X), and GATA-4 (sc-9053x) were purchased from Santa Cruz Biotechnology, Inc. (Santa Cruz, CA,
USA). The equine-specific SF-1 protein was produced by the Sheldon Biotechnology Center, McGill University (Montreal, PQ, Canada).

\section{Characterization of the equine 17 $\beta \mathrm{HSD} 1 \mathrm{cDNA}$ and gene}

The equine $17 \beta \mathrm{HSD} 1$ cDNA was characterized by a combination of RT-PCR, $5^{\prime}$-rapid amplification of cDNA ends (5'-RACE) and genomic cloning. A cDNA fragment was first isolated by RT-PCR using sense primer 1 and antisense primer 2 designed by sequence alignments of $17 \beta$ HSD1 homologs from other species, $100 \mathrm{ng}$ RNA obtained from a preovulatory follicle isolated prior to hCG administration ( $0 \mathrm{~h}$; see below), and the Qiagen OneStep RT-PCR System as directed by the manufacturer (Fig. 1A; RT-PCR1). As a second approach, the $5^{\prime}$ end of equine $17 \beta \mathrm{HSD} 1$ was characterized using the $5^{\prime}$-RACE system version 2.0 (Invitrogen Life Technologies) according to the manufacturer's instructions. Reverse transcription was performed using anti-sense primer 3 (Fig. 1A; $5^{\prime}$-RACE) and $3 \mu \mathrm{g}$ RNA from a preovulatory follicle isolated prior to hCG administration. The first $5^{\prime}$-RACE/PCR was accomplished with sense abridged anchor primer 4 (Invitrogen Life Technologies) and antisense primer 5 , whereas the second $5^{\prime}$-RACE/PCR employed the sense abridged universal amplification primer 6 (Invitrogen Life Technologies) and anti-sense primer 7 (Fig. 1A; $5^{\prime}$-RACE). PCRs consisted of 35 cycles of $94{ }^{\circ} \mathrm{C}$ for $30 \mathrm{~s}, 56{ }^{\circ} \mathrm{C}$ for $1 \mathrm{~min}$, and $72{ }^{\circ} \mathrm{C}$ for $1 \mathrm{~min}$. RT-PCR and $5^{\prime}$-RACE cDNA products were subcloned into the pGEM-T Easy plasmid vector (Promega), and sequenced by the Service de Séquençage de l'Université Laval (Québec, Canada).

Despite numerous attempts to clone the remaining $3^{\prime}$ end of the open reading frame, they remained unsuccessful. As a second approach, an equine genomic library (Stratagene) was screened with the equine RT-PCR 17ßHSD1 cDNA fragment, as previously described (Liu et al. 1999). The probe was labeled with $\left[\alpha_{-}^{32} \mathrm{P}\right] \mathrm{dCTP}$ using the Prime-a-Gene labeling system (Promega) to a final specific activity greater than $1 \times 10^{8}$ c.p.m. $/ \mu \mathrm{g}$ DNA, and hybridization was performed at $68{ }^{\circ} \mathrm{C}$ with QuickHyb hybridization solution (Stratagene). Positive clones were plaque purified through secondary and tertiary screenings, and DNA sequencing was performed commercially as described earlier. The equine 17ßHSD1 genomic sequence was used to design an oligonucleotide $3^{\prime}$ to the coding region. This primer, as well as another oligonucleotide designed from the $5^{\prime}$ end of the cDNA (primers 8 and 9; Fig. 1A; $5^{\prime}$-RACE), allowed RT-PCR amplification of the complete open reading frame, thereby confirming the contiguous cDNA sequence presented herein (Fig. 1A; RT-PCR2). The complete equine genomic sequence was obtained after a 
A

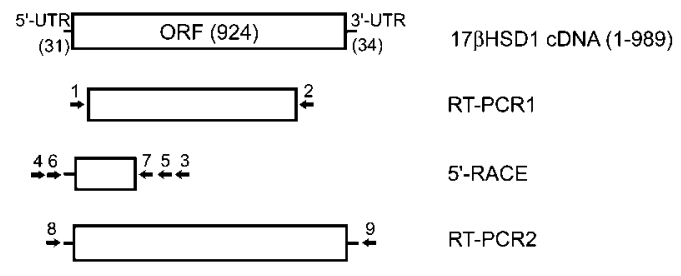

B
1. 5'-CAGATCCATCCCAGAGCTTCAAAGT-3'
2. 5'-GCTCGGTGGTGAAGTAGCGCAG-3'
3. 5'-ATCAAGCCTCCCATGCT-3'
4. 5'-GGCCACGCGTCGACTAGTACGGG\|GGG $\|G G G\| G-3$
5. 5'-CCCGCATTACACACCAGCACGT-3'
6. 5'-GGCCACGCGTCGACTAGTAC-3'
7. 5'-GCGTCTCTCACGTCCAACTGCA-3'
8. 5'-ACTCCCAGCCTCTCCTGGACCGC-3'
9. 5'-TGGGCGGCAGGACGAGCGCCAA-3'

C

1 agcctctcct ggaccgCCgC ctCATGGACC GCACCATCGT GCTCATCACC GGCTGCTCTI CCGGCATCGG CCTGCACCTG GCCCTGCGTC 91 TGGCATCTGA CCCATCCCGG AGTTTCAAAG TGTATGCCAC GCTGCGGGAC CTGACAGCGC AGGGCCCACT GTGGGAGATG GCCCGGGCCC 181 GAGGGTGCCC TCCCGGCTCC CTGGAGACCT TGCAGTTGGA CGTGAGAGAC GCAGATTCCG TGGCCGCTGC CCGGGCACGT GTGACCGAGG 271 GCCGCGTGGA CGTGCTGGTG TGTAATGCGG GCCGGGGCCT GCTCGGGCCG CTCGAGCTGC ACCCGGCGGG CGCCGTGGCC TCCGTGCTGG 361 ACGCGAACGT GGCCGGGACG GTGCGGACGA TTCAGGCCTT CCTGCCGGAC ATGAAGCGCC GCCGCTCGGG ACGCATATTG GTGACCGGGA

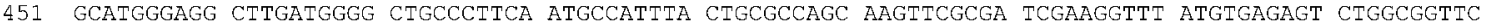
541 TGCTGCAGCC CITTGGGGTC CACGTGAGCC TCATTGAGTG CGGCCCGGTG CACACCGCCT TCCAGGAAA GCTGGAGGGC GGCCCGGGCG 631 GGGCGCTGGA CGGCGCGGAC GCCGACACCC GCGACCTCTI CTCCCGCTAC CTGCGCCACI GCGAGCAGAT GTACCGCGAG GTGGCACAGG 721 ACCCGGAGGC GGTGACGGAg GTCTTCCTCA CCGCGCTGCG CGCCCCGCGG CCGGCCCTGC GCTACTTCAg CACCGAGCGC ITCCTGCCCC 811 TGGTCCAGCT GCGCCTCTCC GACCCCAGCG GCCGCAGCTA CGTCGCCGCC ATGCACAGCG CGGTGTTCGC CGACGAGCCC GCCCAGGACC 901 CCGACGGCGC CCGGGCCGAG GCCAGAGACG GAGAAGCCGG GGAGCCCTGA gcttggcget cgtcctgccg cCCa

Figure 1 Cloning strategy for equine $17 \beta H S D 1$. (A) The open reading frame (ORF) of the equine $17 \beta H S D 1 \mathrm{cDNA}$ is depicted as an open box, whereas the $5^{\prime}$ - and $3^{\prime}$-untranslated regions (UTR) are shown as lines; the size in base pairs of each element is given in parenthesis. Equine $17 \beta \mathrm{HSD} 1$ was characterized by a combination of RT-PCR, $5^{\prime}$-RACE, and a second round of RT-PCR with an anti-sense primer obtained through genomic cloning and encompassing the entire ORF, as described in Materials and Methods; arrows and numbers show the relative position, orientation, and identity of oligonucleotides used in each cloning procedure. (B) List of oligonucleotides used for equine $17 \beta \mathrm{HSD} 1 \mathrm{cloning}$. The abridged anchor primer (4) and abridged universal amplification primer (6) are components of the $5^{\prime}$-RACE system (Invitrogen Life Technologies). (C) Sequence of 17ßHSD1 cDNA. 5' - and $3^{\prime}$-UTRs are shown in lowercase letters, whereas the ORF is presented in uppercase letters with the start (ATG) and stop (TGA) codons in bold. The complete nucleotide sequence of the equine 17ßHSD1 cDNA was submitted to GenBank (Accession number DQ418451).

number of sequencing reactions using equine $17 \beta$ HSD1-specific primers. A comparison of the cDNA and the resulting genomic DNA sequences was used to determine the gene structure of equine $17 \beta$ HSD1 as well as the exon-intron junctions (Fig. 2).

\section{Equine tissues}

Equine preovulatory follicles and corpora lutea were isolated at specific stages of the estrous cycle from Standardbred and Thoroughbred mares, 3-10 years old and weighing approximately $375-450 \mathrm{~kg}$, as previously

A

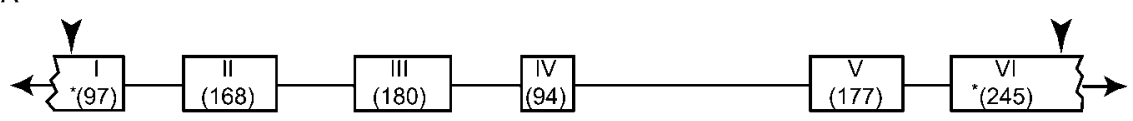

B

\begin{tabular}{|c|c|c|c|c|}
\hline Exon & & Intron & & Exor \\
\hline & & & $\mathrm{G}^{001}$ CACTC... & 1 \\
\hline 1 & $\ldots$ TCAAAG ${ }^{-28}$ gtacgt... & 1 (108 bp) & 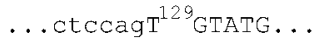 & 2 \\
\hline 2 & ...TGCTGG ${ }^{296}$ gtgagt... & $2(143 b p)$ & 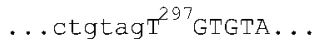 & 3 \\
\hline 3 & $\ldots$ TGATGG $^{476}$ gtgagt... & $3(131 \mathrm{bp})$ & 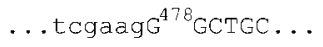 & 4 \\
\hline 4 & ...GGTCCA ${ }^{570}$ gtgagt... & $4(443 b p)$ & ..ccgcagc ${ }^{5 / 1}$ GTGAG. . & 5 \\
\hline 5 & $\ldots$ GACGGA ${ }^{747}$ agtggg . . & $5(89 b p)$ & $\ldots$ gсcgcaG ${ }^{78} \mathrm{GTCTT} \ldots$ & 6 \\
\hline 6 & . . AATAAT & & & \\
\hline
\end{tabular}

Figure 2 Equine $17 \beta H S D 1$ gene structure. (A) Schematic representation of the equine $17 \beta H S D 1$ gene structure. Exons are shown as boxes and introns are presented as lines. All elements are drawn to scale. Roman numerals indicate the exon number, whereas numbers in parentheses show the number of nucleotides in the exon. Numbers next to asterisk, represent numbers of nucleotides in the exon within the open reading frame. (B) Exon/intron boundaries of the equine $17 \beta H S D 1$ gene. Exonic sequences at each splice junction are presented in uppercase letters, whereas intronic sequences are shown in lowercase letters. Numbers in parentheses represent the exact size of the intron. The complete nucleotide sequence of the equine $17 \beta H S D 1$ gene was submitted to GenBank (Accession number DQ418450). 
described (Sirois \& Doré 1997). Briefly, when preovulatory follicles reached $35 \mathrm{~mm}$ in diameter during estrus, the ovulatory process was initiated by injection of hCG (2500 IU, i.v.). Ovariectomies were then performed via colpotomy using an ovariotome at $0,12,24,30,33,36$, or $39 \mathrm{~h}$ post-hCG ( $n=4-6$ mares/time point). Follicles were dissected into preparations of follicle wall (theca interna with attached granulosa cells) or further dissected into separate isolates of granulosa cells and theca interna, as previously described (Sirois et al. 1991). Ovariectomies were also performed on day 8 of the estrous cycle (day $0=$ day of ovulation) to obtain corpora lutea ( $n=3$ mares). Testicular tissues were obtained from the Large Animal Hospital of the Faculté de Médecine Vétérinaire (Université de Montréal) following a routine castration, whereas other nonovarian tissues were collected at a local slaughterhouse. All animal procedures were approved by the Institutional Animal Use and Care Committee.

\section{RNA extraction and semi-quantitative RT-PCR/Southern analysis}

Total RNA was isolated from tissues with TRIzol reagent (Invitrogen Canada, Inc.), according to manufacturer's instructions using a Kinematica PT 1200C Polytron Homogenizer (Fisher Scientific, Montréal, Canada). The OneStep RT-PCR System (Qiagen) was used for semi-quantitative analysis of $17 \beta \mathrm{HSD} 1$ and rpL7a mRNA levels (control gene) in equine tissues. Reactions were performed as directed by the manufacturer, using sense ( $5^{\prime}$-ACCTTGCAGTTGGACGTGAGAGA- $\left.3^{\prime}\right)$ and antisense $\left(5^{\prime}\right.$-TCGCGGTACATCTGCTCGCAGT- $\left.3^{\prime}\right)$ primers specific for equine $17 \beta \mathrm{HSD} 1$. Sense (5'-ACAGGACATCCAGCCCAAACG- $3^{\prime}$ ) and anti-sense ( $5^{\prime}$-GCTCCTTTGTCTTCCGAGTTG- $3^{\prime}$ ) primers specific for equine rpL7a were designed from a published sequence deposited in GenBank (Accession no. AF508309). These reactions resulted in the production of $17 \beta \mathrm{HSD} 1$ and $\mathrm{rpL} 7 \mathrm{a}$ DNA fragments of 503 and $516 \mathrm{bp}$ respectively. Each reaction was performed using $100 \mathrm{ng}$ total RNA, and cycling conditions were one cycle of $50{ }^{\circ} \mathrm{C}$ for $30 \mathrm{~min}$ and $95{ }^{\circ} \mathrm{C}$ for $15 \mathrm{~min}$, followed by a variable number of cycles of $94{ }^{\circ} \mathrm{C}$ for $1 \mathrm{~min}, 60{ }^{\circ} \mathrm{C}$ for $1 \mathrm{~min}$, and $72^{\circ} \mathrm{C}$ for $1 \mathrm{~min}$. The number of cycles used was optimized for each gene to fall within the linear range of PCR amplification, and were 26 and 18 cycles for $17 \beta$ HSD 1 and rpL7a respectively. Following PCR amplification, samples were subjected to electrophoresis on 2\% tris-acetate EDTA (TAE)-agarose gels, transferred to nylon membranes, and hybridized with corresponding radiolabeled 17ßHSD1 and rpL7A cDNA fragments using QuikHyb hybridization solution (Stratagene). Membranes were exposed to a phosphor screen, and signals were quantified by means of a Storm imaging system using the ImageQuant software version 1.1 (Molecular Dynamics, Amersham Biosciences).

\section{Granulosa cell nuclear extracts and electrophoretic mobility shift assays (EMSAs)}

Equine granulosa cells were obtained from preovulatory follicles isolated at 0 and $30 \mathrm{~h}$ post-hCG and nuclear extracts were prepared as described (Sirois $\mathrm{et} \mathrm{al}$. 1993, Liu et al. 1999). Protein concentration in each extract was determined by the method of Bradford (1976). EMSAs were performed as described (Sirois et al. 1993, Liu et al. 1999), with minor modifications. Briefly, extracts of nuclear proteins $(0.5 \mu \mathrm{g} /$ reaction $)$ were incubated with 40000 c.p.m. of end-labeled $-230 /-3017 \beta \mathrm{HSD} 1$ promoter fragment and $1 \mu \mathrm{g}$ poly $(\mathrm{dI} / \mathrm{dC}$ ) (Amersham Biosciences) in a final volume of $20 \mu \mathrm{l}$ binding buffer containing $15 \mathrm{mM}$ Tris- $\mathrm{HCl}(\mathrm{pH}$ 7.5), $1 \mathrm{mM}$ EDTA, $100 \mathrm{mM} \mathrm{KCl}, 5 \mathrm{mM} \mathrm{MgCl}_{2}, 5 \mathrm{mM}$ dithiothreitol, and $12 \%$ (v/v) glycerol. Cold oligonucleotide pairs, both wild type and mutated, were used in 50 times molar excess in order to determine the identity of bound sequence. When antibodies (Santa Cruz Biotechnology) were used in supershift EMSAs, the nuclear extract was first incubated for $1 \mathrm{~h}$ on ice with the antiserum prior to the addition of other reagents. Binding complexes were resolved by $5 \%$ acrylamide, $0 \cdot 5 \times$ tris-borate EDTA (TBE) gel electrophoresis.

\section{Protein extracts, anti-equine SF-1 antibody, and immunoblot analysis}

Preovulatory follicle extracts were prepared as previously described (Filion et al. 2001). Briefly, tissue was homogenized and sonicated on ice in TED buffer $(20 \mathrm{~mm}$ Tris $(\mathrm{pH} 8 \cdot 0), 50 \mathrm{~mm}$ EDTA, and $0 \cdot 1 \mathrm{~mm}$ diethyldithiocarbamic acid) containing $1.0 \%$ Tween. The sonicate was centrifuged at $16000 \mathrm{~g}$ for $15 \mathrm{~min}$ at $4{ }^{\circ} \mathrm{C}$. The recovered supernatant (whole cell extract) was stored at $-80{ }^{\circ} \mathrm{C}$ until electrophoretic analyses were performed. Protein concentration was determined by the method of Bradford (1976; Bio-Rad protein assay). Samples $(50 \mu \mathrm{g}$ proteins) were resolved by one-dimensional SDS-PAGE and electrophoretically transferred to polyvinylidene difluoride membranes (Filion et al. 2001). The equine-specific anti-SF-1 polyclonal antibody was generated as previously described (Brown et al. 2004) using a peptide fragment encompassing amino acids $\mathrm{Cys}^{248}$ to $\mathrm{Ser}^{262}$ (Sheldon Biotechnology Center). Membranes were incubated with the polyclonal antiequine SF-1 antibody (1:1000) and immunoreactive proteins were visualized on Kodak X-OMAT AR film (Eastman Kodak Co., Rochester, NY, USA) after incubation with the horseradish peroxidase-linked donkey anti-rabbit secondary antibody (1:10 000 dilution) and the enhanced chemiluminescence system (ECL Plus), following the manufacturer's protocol (Amersham Pharmacia Biotech). 


\section{Statistical analysis}

One-way ANOVA was used to test the effect of time after hCG administration on levels of 17ßHSD1 mRNA in samples of follicle wall, corpora lutea, theca interna, and granulosa cells. 17ßHSD1 transcript levels were normalized with the control gene rpL7a before analysis. When ANOVAs indicated significant differences $(P<0 \cdot 05)$, Dunnett's test was used for multiple comparisons of individual means. Statistical analyses were performed using JMP software (SAS Institute, Inc., Cary, NC, USA).

\section{Results}

\section{Characterization of the equine 17ßHSD1 cDNA, gene, and protein}

To clone the equine 17ßHSD1 transcript, RT-PCR was performed on ovarian RNA using oligonucleotide primers designed by sequence alignment of $17 \beta \mathrm{HSD} 1$ homologs in other species. The resulting cDNA fragment (Fig. 1A; RT-PCR1) was sequenced and found to be highly homologous to $17 \beta \mathrm{HSD} 1$ transcripts identified thus far. The $5^{\prime}$-RACE reactions yielded a cDNA product corresponding to the remaining $5^{\prime}$ end coding regions, as well as the $5^{\prime}$-untranslated region (Fig. 1A; 5'-RACE). An equine genomic library was screened with a cDNA probe obtained by RT-PCR. The genomic sequence of equine $17 \beta \mathrm{HSD} 1$ was determined by performing several sequencing reactions (GenBank Accession number DQ418450) and used to derive the $3^{\prime}$ end of the equine 17ßHSD1 cDNA, as well as the genomic structure. It was determined to have six exons (Fig. 2A), identical to what is observed for the human and mouse genes. The exon-intron junctions were also shown to be conserved (Fig. 2B). After sequencing of the $17 \beta H S D 1$ gene, equine-specific primers were designed and used to amplify a RT-PCR product that extended the entire length of the cDNA open reading frame, thereby confirming that all RT-PCR products were derived from the same transcript (Fig. 1A; RT-PCR2). The deduced $982 \mathrm{bp}$ primary transcript encoded a $924 \mathrm{bp}$ open reading frame (Fig. 1A; GenBank Accession number DQ418451), which predicted a protein of 308 amino acids.

The predicted protein is highly conserved when compared with human (NP_000404), marmoset (AAG01115), rat (AAH86365), and mouse (CAA61770) 17ßHSD1 proteins (Fig. 3). Equine $17 \beta$ HSD1 has $73.3 \%$ identity at the amino acid level and $81.2 \%$ identity at the nucleic acid level relative to human 17ßHSD1 (NM_000413). Homology was lost when the carboxy terminus of the proteins was examined and the proteins also exhibited variability in sizes; the equine $17 \beta \mathrm{HSD} 1$ is 20 amino acids shorter than human $17 \beta \mathrm{HSD} 1$, which is 16 amino acids shorter than both rodent proteins presented (Fig. 3). The marmoset protein may be incomplete in its amino terminus.

\section{Tissue distribution of equine 17ßHSD1 mRNA}

RT-PCR/Southern blot analyses were used to evaluate the expression of equine $17 \beta \mathrm{HSD} 1 \mathrm{mRNA}$ in various tissues. High levels of $17 \beta$ HSD 1 transcript were detected in a preovulatory follicle isolated prior to

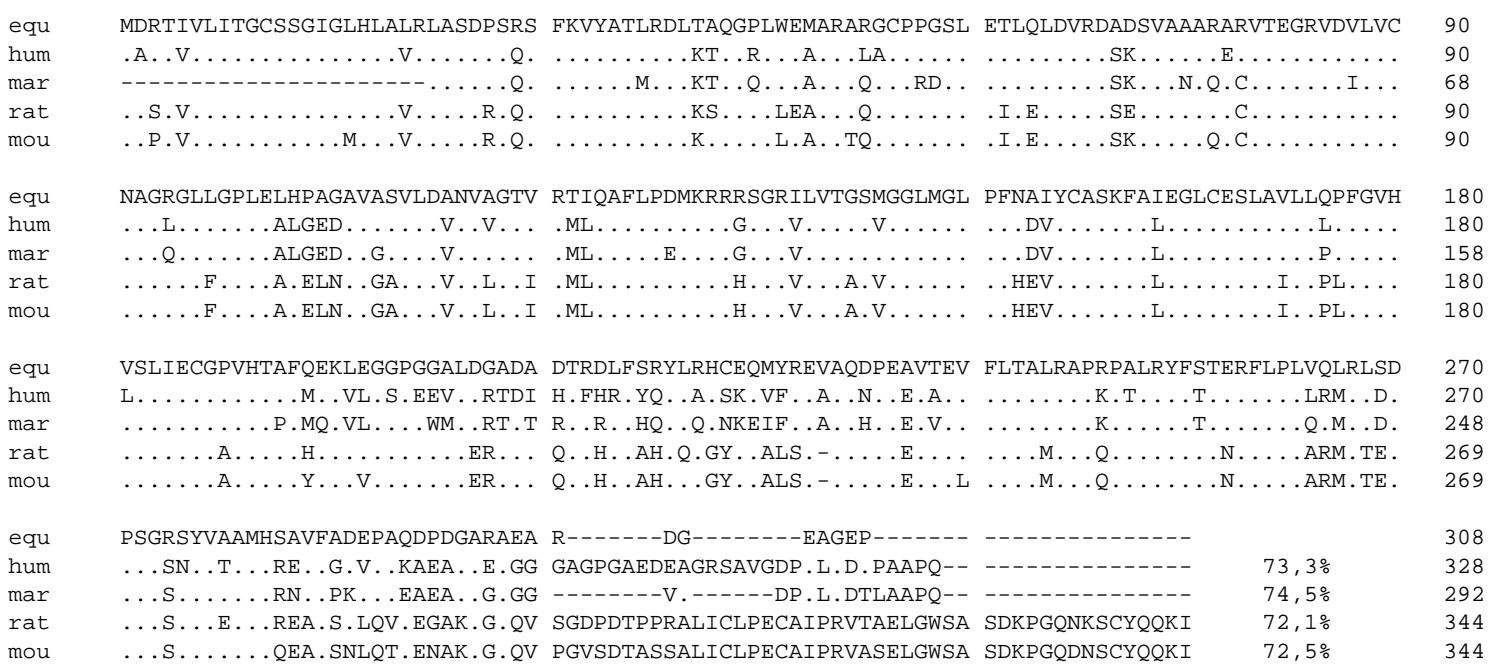

Figure 3 Equine $17 \beta \mathrm{HSD} 1$ predicted amino acid sequence. (A) The amino acid sequence of equine (equ) $17 \beta \mathrm{HSD} 1$ is aligned with the human (hum), marmostet (mar), rat, and mouse (mou) homologs. Identical residues are marked with a printed period, hyphens indicate gaps in protein sequences created to optimize alignment, and numbers on the right refer to the last amino acid on that line. The percentage presented at the end of each sequence represents the sequence's homology to the equine protein. 
hCG and in a placenta sample; whereas the message was very low or absent in all other tissues examined (Fig. 4A). Abundance of the control gene rpL7a remained constant in all the tissues studied (Fig. 4B).

\section{Regulation of 17ßHSD1 mRNA in preovulatory follicles}

The regulation of equine $17 \beta \mathrm{HSD} 1 \mathrm{mRNA}$ in preovulatory follicles isolated during estrus between 0 and $36 \mathrm{~h}$ after hCG treatment and in corpora lutea on day 8 of the estrous cycle was examined by RT-PCR/Southern blot. The results clearly demonstrated a dramatic decrease in $17 \beta$ HSD1 transcript expression in equine follicles during the hCG-induced ovulatory/luteinization process. Elevated levels of $17 \beta \mathrm{HSD} 1 \mathrm{mRNA}$ were observed prior to hCG $(0 \mathrm{~h})$ with a pronounced downregulation observed $12 \mathrm{~h}$ post-hCG. Levels remained low, almost undetectable, in samples isolated between 24 and $36 \mathrm{~h}$ post-hCG, as well as in day 8 corpus luteum (Fig. 5A). No variation was observed in levels of rpL7a transcript in follicle wall and corpora lutea preparations (Fig. 5B). When results from multiple follicles and corpora lutea were expressed as ratios of $17 \beta \mathrm{HSD} 1$ to $\mathrm{rpL} 7 \mathrm{a}$, a significant decrease in 17 $\beta$ HSD1 transcript was observed in follicles between 12 and $36 \mathrm{~h}$ after hCG treatment and in corpora lutea $(P<0.05$; Fig. $5 \mathrm{C})$.

In order to determine the contributions of the different steroidogenic cell types that make up the
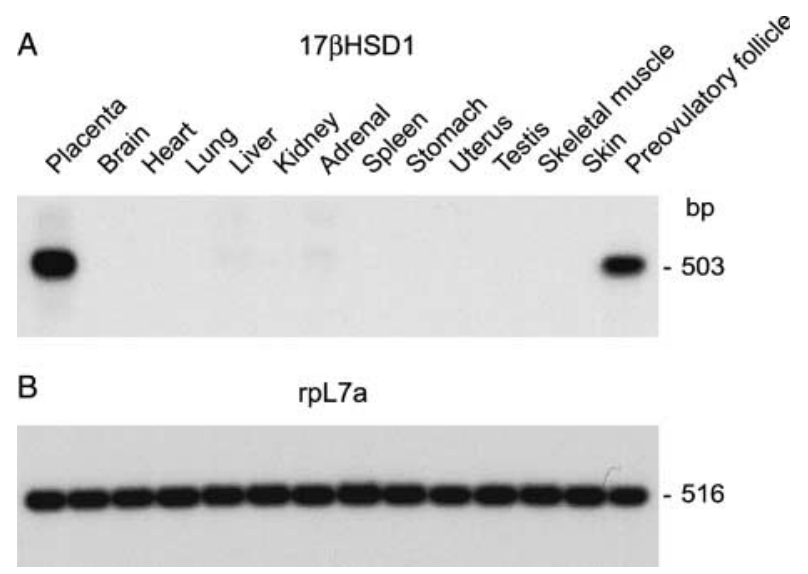

Figure 4 Expression of $17 \beta$ HSD transcript in equine tissues. RNA extracts were prepared from various equine tissues, and samples (100 ng) were analyzed for $17 \beta \mathrm{HSD} 1$ and $\mathrm{rpL} 7 \mathrm{a}$ (control gene) by semi-quantitative RT-PCR/Southern blotting, as described in Materials and methods. (A) Expression of $17 \beta \mathrm{HSD} 1 \mathrm{mRNA}$ in equine tissues. (B) Expression of rpL7a mRNA in equine tissues. The number of PCR cycles for each gene was within the linear range of amplification, and they represented 26 and 18 cycles for $17 \beta \mathrm{HSD} 1$ and $\mathrm{rpL} 7 \mathrm{a}$ respectively. The follicle wall extract was prepared from a preovulatory follicle obtained prior to (i.e. $0 \mathrm{~h}$ ) hCG treatment. Numbers on the right indicate the size of the PCR fragment.
A

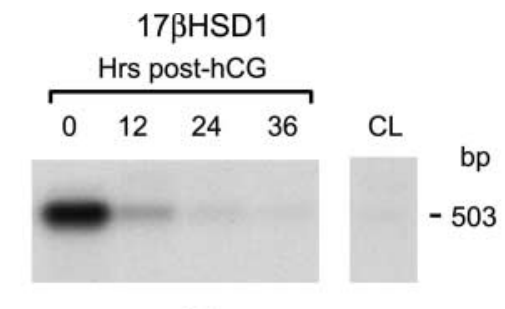

B

rpL7a

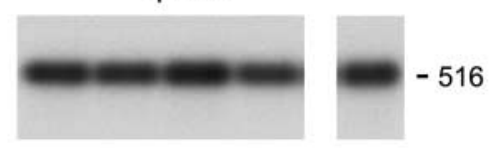

C

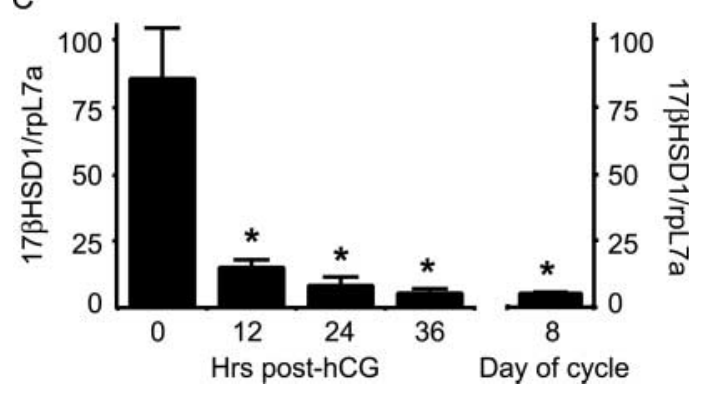

Figure 5 Downregulation of 17ßHSD1 mRNA by hCG in equine preovulatory follicles. RNA extracts were prepared from the wall of preovulatory follicles isolated between 0 and $36 \mathrm{~h}$ after $\mathrm{hCG}$ and from corpora lutea $(\mathrm{CL})$ isolated on day 8 of the estrous cycle. RNA samples (100 ng) were analyzed for $17 \beta \mathrm{HSD} 1$ and rpL7a by semi-quantitative RT-PCR/Southern blotting, as described in Materials and Methods. (A) Regulation of 17BHSD1 mRNA in equine follicles (one representative follicle per time point).

(B) Constitutive expression of rpL7a mRNA in the same follicles. Numbers on the right depict the size of the PCR fragment.

(C) Relative changes in 17ßHSD1 mRNA in equine follicles after hCG treatment. The 17ßHSD1 signal was normalized with the control gene $\mathrm{rpL} 7 \mathrm{a}$, and results are presented as a ratio of $17 \beta \mathrm{HSD} 1$ to rpL7a ( $n=5-6$ distinct follicles (i.e. animals) per time point, and $n=3$ corpora lutea). Bars marked with an asterisk are significantly different from $0 \mathrm{~h}$ post-hCG $(P<0 \cdot 05)$.

follicle wall, granulosa and theca interna cells were isolated from follicles obtained between 0 and $39 \mathrm{~h}$ after hCG treatment (Fig. 6). The results revealed that the granulosa cell layer was the sole contributor of $17 \beta$ HSD1 transcript expression. In this cell type, a significant decrease in 17ßHSD1 mRNA was observed 12-39 h after hCG $(P<0 \cdot 05$; Fig. 6A). 17ßHSD1 mRNA expression was low to absent in all theca interna samples examined (Fig. 6B).

\section{Binding activity of nuclear extract proteins to the 17ßHSD1 proximal promoter}

Genomic cloning led to the characterization of a $1.4 \mathrm{~kb}$ fragment of $5^{\prime}$-flanking DNA region (Fig. 7). Use of transcription start site prediction software (www.fruitfly. org/seq_tools/promoter.html) identified a putative 
A
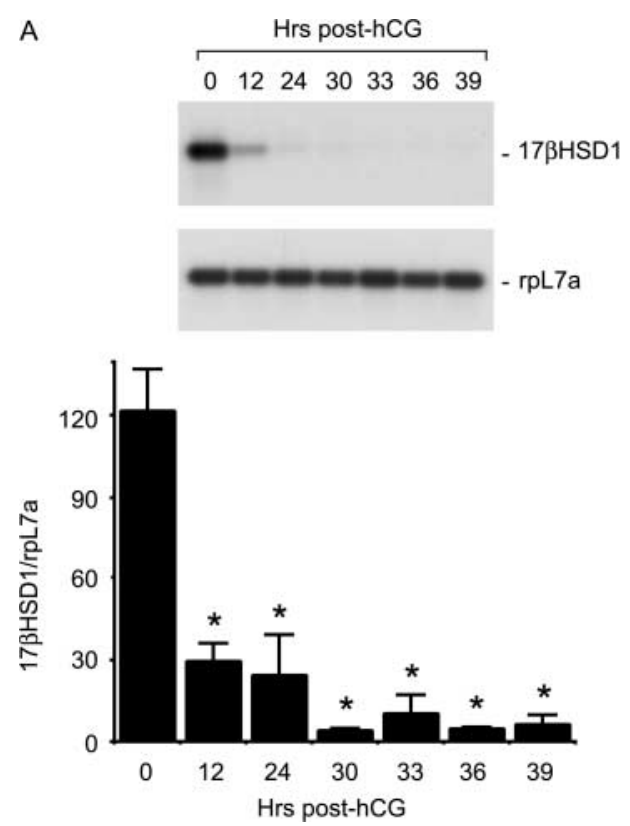

B
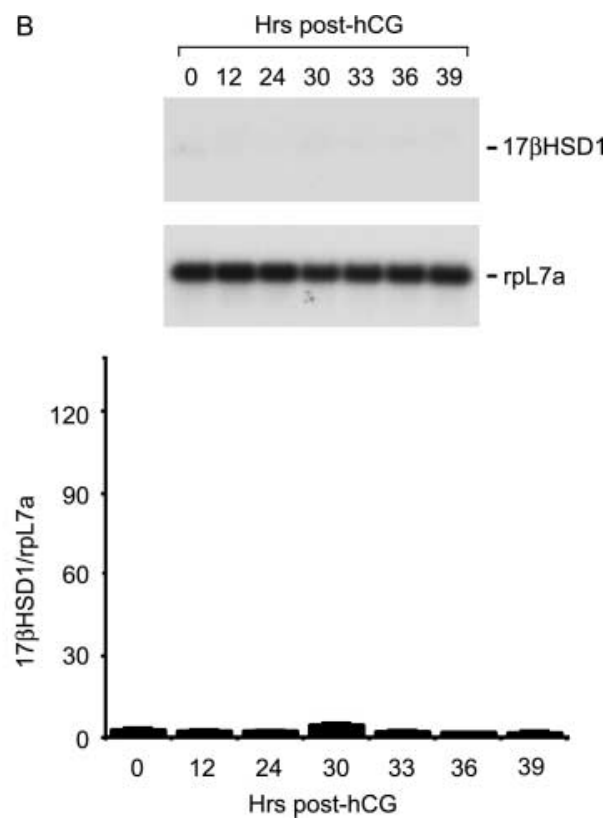

Figure 6 Cell type-dependent expression and regulation of $17 \beta H S D 1$ mRNA in equine preovulatory follicles. RNA extracts were prepared from granulosa cells $(A)$ and theca interna $(B)$ isolated from equine preovulatory follicles between 0 and $39 \mathrm{~h}$ post-hCG, and samples (100 $\mathrm{ng}$ ) were analyzed for $17 \beta \mathrm{HSD} 1$ and $\mathrm{rpL7a}$ by semi-quantitative RT-PCR/Southern blotting, as described in Materials and Methods. Autoradiograms show representative results of $17 \beta \mathrm{HSD} 1$ and $\mathrm{rpL} 7 \mathrm{a}$ mRNA levels (one sample per time point). The $17 \beta \mathrm{HSD} 1$ signal was normalized with $\mathrm{rpL} 7 \mathrm{a}$, and results are presented as a ratio of $17 \beta \mathrm{HSD} 1$ to $\mathrm{rpL7a}$ (mean \pm S.E.M.; $n=4$ samples (i.e. mares) per time point). Bars marked with an asterisk are significantly different from $0 \mathrm{~h}$ post-hCG $(P<0 \cdot 05)$.

transcription start site $23 \mathrm{bp}$ upstream of the ATG start codon (Fig. 7). Putative cis-acting elements located within $300 \mathrm{bp}$ upstream of the transcription start site were identified with the TRANSFAC database (http:// motif.genome.jp/) and included a C/EBP, an AP-2, two GATA, an SF-1, a NFкB, two Sp1, and a cAMP response element (CRE) element. To determine whether hCG affected the binding of putative transcriptional regulators to the $-230 /-30$ fragment $(+1$ representing the transcriptional start site) of the $17 \beta \mathrm{HSD} 1$ promoter, nuclear extracts from granulosa cells isolated from preovulatory follicles obtained at 0 and $30 \mathrm{~h}$ post-hCG were used in EMSA. Results demonstrated that a major protein/DNA complex was formed with nuclear extracts at $0 \mathrm{~h}$ post-hCG (Fig. 8A, lane 2). The use of $30 \mathrm{~h}$ post-hCG nuclear extracts did not affect the migration of the band, but resulted in a net decrease in protein binding (Fig. 8A, lane 3). To characterize the specificity of protein/DNA interactions, EMSAs were performed using molar excess of unlabeled oligonucleotides (Fig. 8D) containing various putative transcription factor-binding sites present within the $-230 /-30$ fragment (Fig. 8A, lanes 4-7). Results showed that competitors containing Spl-binding sites reduced protein-promoter complex formation (Fig. 8A, lane 5), whereas no effect was observed when competitors containing the first GATA or C/EBP and AP-2 elements were used (Fig. 8A, lanes 4 and 6). Interestingly, the signal was completely abolished when an oligonucleotide contained both $\mathrm{SF}-1 / \mathrm{NF} \kappa \mathrm{B}$ and the second GATA binding sites was used as a competitor (Fig. 8A, lane 7).

To further confirm the specificity of binding to the putative binding sites, individual transcription factorspecific regions were mutated and again used as competitors. The previously observed SF-1/NFкB/ GATA competition was greatly reduced when either sites were mutated, indicating a putative and collaborative binding instance (Fig. 8B, lanes 4 and 5). To investigate the potential presence of $\mathrm{NF} \kappa \mathrm{B}, \mathrm{SF}-1$, and GATA protein in the binding complex, supershift EMSAs were performed using antibodies specific to the p50 and p65 subunits of NF $\kappa B$, as well as antibodies specific for GATA-4 and equine SF-1. The intensity of the major band decreased when the anti-p65 antibody was used (Fig. 8B, lane 7 vs lane 2, band (a)), and a clear supershift band appeared when the anti-equine SF-1 antibody was used (Fig. 8C, lane 3 vs lane 2, band (b)) No change in intensity was discernable when the antip50 or anti-GATA4 antibodies were used (Fig. 8B, lanes 6 and 8 vs lane 2 , band (a)). 


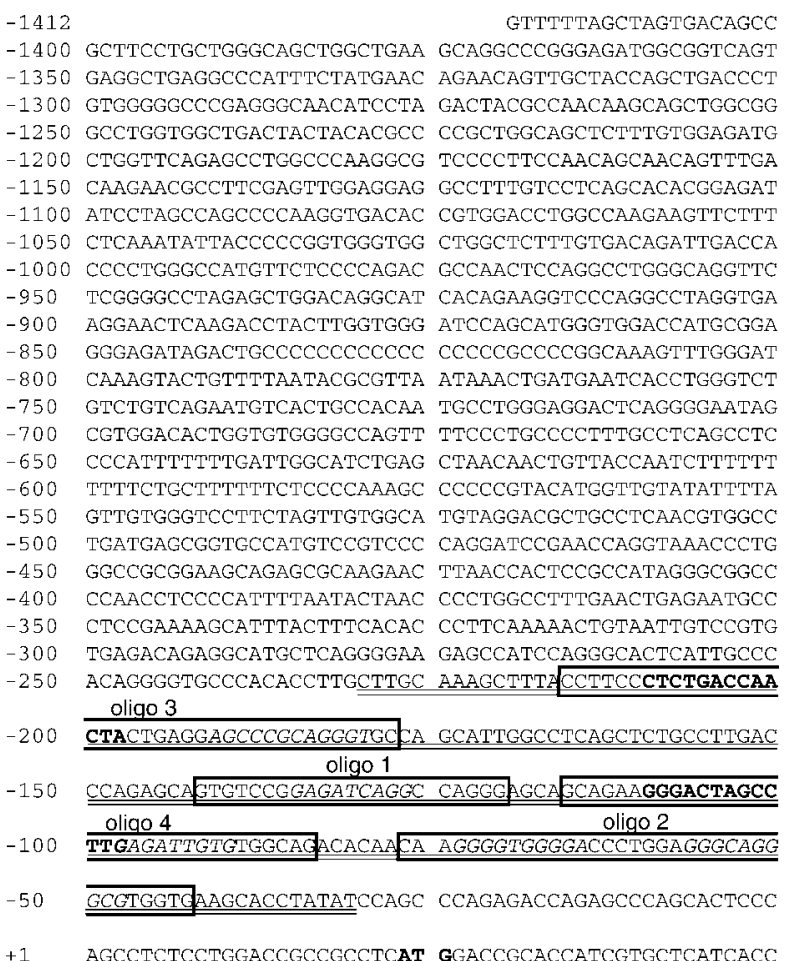

Figure 7 Isolation and characterization of the equine $17 \beta$ HSD1 promoter. Numbering is relative to the putative transcription start site $(+1)$ and the ATG translation start codon is in bold. The oligos used in competition assays are boxed. Putative cis-acting elements located within the $300 \mathrm{bp}$ upstream of the start site are as follows: oligo 1, GATA (italic); oligo 2, Sp1 (italic); oligo 3,

C/EBP (bold) and AP-2 (italic); and oligo 4, NFKB/SF-1 (bold) and GATA (italic). The probe used in binding assays is double underlined. The nucleotide sequence of the $1.4 \mathrm{~kb}$ promoter fragment is part of the genomic sequence deposited to GenBank (Accession number DQ418450).

\section{Anti-equine SF-1 antibody specificity and expression of SF-1 protein in equine preovulatory follicles}

The SF-1 antibody specificity and the hCG-dependent downregulation of the SF-1 protein were demonstrated at the protein level by immunoblot in follicles at 0 and $39 \mathrm{~h}$ post-hCG. As shown, the antibody raised in rabbit recognized the equine SF-1 protein from preovulatory follicle cell extracts, with two bands appearing at approximately $52 \mathrm{kDa}$ (Fig. 8E). Gonadotropin treatment resulted in a marked decrease in SF-1 protein expression (Fig. 8E).

\section{Discussion}

This is the first study to identify hCG as a negative regulator of $17 \beta \mathrm{HSD} 1 \mathrm{mRNA}$ expression during the follicular luteinization in granulosa cells of a monoovulatory species. Follicular luteinization/ovulation has previously been associated with dramatic changes in steroidogenic enzyme expression. Enzymes responsible for androgen and estrogen biosynthesis have been shown to be downregulated, whereas the expression of those responsible for enhanced progesterone synthesis is upregulated (Fortune 1994, Richards 1994, RonenFuhrmann et al. 1998, Sandhoff et al. 1998). This study thereby provides an additional molecular basis for the decrease in $17 \beta$-estradiol production. Previous investigations of $17 \beta \mathrm{HSD} 1$ in the ovary have included its detection by northern blot in the rat (Ghersevich et al. 1994), RT-PCR in humans (Nelson et al. 2001), in situ hybridization, and Southern blotting in mice (Sha et al. 1997, Pelletier et al. 2004), as well as in human corpora lutea by immunohistochemistry (Vaskivuo et al. 2002). It has been detected in the granulosa cells of developing follicles in immature and mature rats (Akinola et al. 1997), and its regulation during the ovulatory process has been examined in rodents; however, it was limited by the use of immature hypophysectomized rats (Ghersevich et al. 1994).

This study characterizes the hCG-dependent downregulation of $17 \beta \mathrm{HSD} 1$ transcript expression in a series of preovulatory follicles from a monoovulatory species. Previous reports using immature hypophysectomized rats have demonstrated that recombinant follicle stimulating hormone ( $\mathrm{FSH}$ ) had a stimulatory effect on 17ßHSD1 transcript and protein expression, and that further treatment with hCG resulted in a downregulation of $17 \beta \mathrm{HSD} 1 \mathrm{mRNA}$, visible after 1 day of treatment (Ghersevich et al. 1994). The present study shows that this downregulation is already visible $12 \mathrm{~h}$ after hCG treatment in the equine preovulatory follicle. Therefore, the results presented herein are consistent with the previous report and further establish the rapidity of $17 \beta \mathrm{HSD} 1$ transcript downregulation.

The molecular control of the $17 \beta H S D 1$ gene in granulosa cells has remained largely uncharacterized. It has been shown, however, that AP-2 can interfere with Sp1 binding, and that GATA-3 can prevent transcription of constructs containing the $17 \beta \mathrm{HSD} 1$ proximal promoter in choriocarcinoma cells (Piao et al. 1997). Further, retinoic acids and activin-A have been demonstrated to induce 17 $\beta$ HSD1 mRNA in human JEG-3 cells and cultured rat granulosa cells respectively (Piao et al. 1997, Ghersevich et al. 2000, Zhu et al. 2002). The present study demonstrates for the first time the gonadotropin-dependent decrease in nuclear extract binding to the $17 \beta$ HSD 1 proximal promoter and identifies SF-1 and $\mathrm{NF} \kappa \mathrm{B}$ as putative cis-acting elements in $17 \beta \mathrm{HSD} 1$ transcriptional regulation. Interestingly, the transcript for SF-1 has previously been shown to be downregulated after hCG treatment in these same follicles (Boerboom et al. 2000), thereby supporting the present observation of SF-1 protein downregulation after hCG. Moreover, the inverted SF-1-binding site identified in this study is identical to that reported for 
A

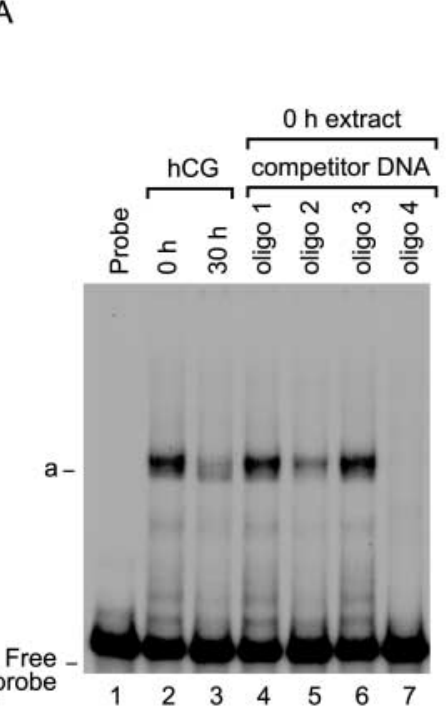

B

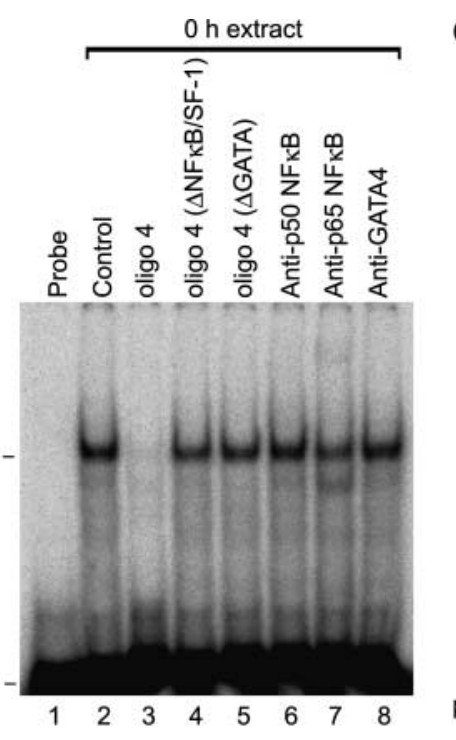

C

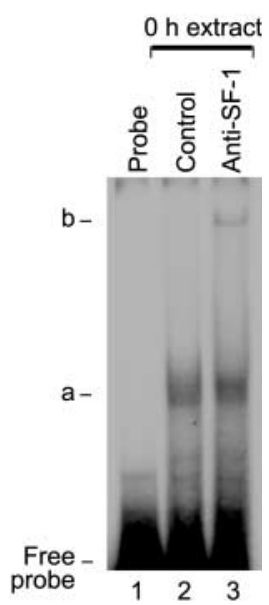

D

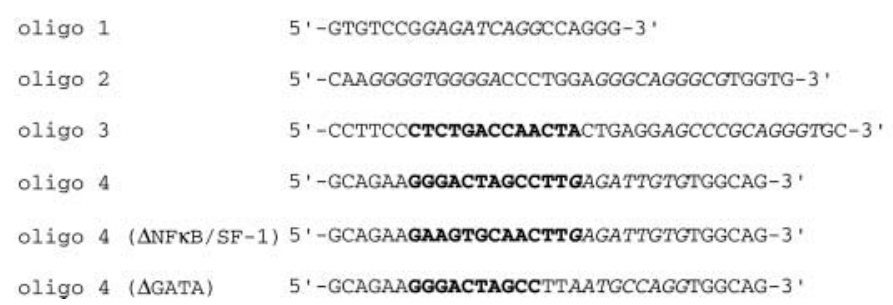

E

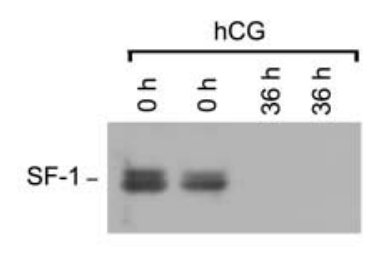

Figure 8 Gonadotropin-dependent regulation of DNA-binding activities in equine granulosa cell nuclear extracts. (A) Nuclear protein extracts were prepared from granulosa cells of follicles isolated before $(0 \mathrm{~h})$ and after ( $30 \mathrm{~h}$ ) hCG treatment (lanes 2 and 3), as described in Materials and methods. Extracts were incubated with ${ }^{32} \mathrm{P}$-labeled $17 \beta \mathrm{HSD} 1$ promoter fragment $-230 /-30$, and protein-DNA interactions were studied by EMSAs. For reference purposes, the major protein-DNA complex is designated as band $a$. Competitive EMSAs were performed in the presence of various unlabeled competitor DNA (lanes 4-7). (B) Competitive EMSAs and supershift assays were performed in the presence of nuclear extracts prepared from granulosa cells from follicles isolated prior to hCG-treatment, ${ }^{32} \mathrm{P}$-labeled oligo 4 and various unlabeled competitor wild-type and mutated DNA, as well as with $\mathrm{NF} \kappa \mathrm{B}$ and GATA-specific antibodies. (C) Supershift assay performed in the presence of nuclear extracts prepared from granulosa cells from follicles isolated prior to hCG-treatment, ${ }^{32} \mathrm{P}$-labeled oligo 4 and an SF-1-specific antibody. (D) Sequences of competitor wild-type and mutated $(\Delta)$ oligonucleotides. (E) SF-1 antibody specificity and regulation of SF-1 protein by $h C G$ in equine preovulatory follicles. Protein extracts were prepared from preovulatory follicles isolated 0 and $36 \mathrm{~h}$ after $\mathrm{hCG}$ treatment ( $n=2$ samples (i.e. mares) per time point) and were analyzed by one-dimensional SDS-PAGE and immunoblotting using a specific polyclonal antibody raised against a fragment of the equine SF-1 protein, as described in Materials and Methods. Results from protein extracts ( $50 \mu \mathrm{g} / \mathrm{lane}$ ) are shown. The marker on the left indicates the expected position of the SF-1 protein.

the bovine CYP11A gene, encoding the cytochrome $\mathrm{P} 450$ side-chain cleavage enzyme, and this sequence has been demonstrated to bind the SF-1 protein (Liu \& Simpson 1997). Even though incubation of the anti-p65 $\mathrm{NF} \kappa \mathrm{B}$ antibody with the nuclear extract did not lead to the formation of an antibody-protein-DNA complex, it did lead to the displacement of binding of nuclear proteins to the oligonucleotide, and the level of displacement may in part be due to the antibody raised against the human protein. Nonetheless, the decrease in complex formation observed using this antibody is indicative that this transcription factor may be involved in promoter regulation. Interestingly, NFKB has been demonstrated to activate transcription of the CYP19A1 gene (Fan et al. 2005). CYP19A1 encodes the cytochrome P450 enzyme aromatase, whose role in estrogen biosynthesis has largely been characterized (Simpson et al. 2005). In that study, it was shown that the activation of $\mathrm{NF} \kappa \mathrm{B}$ resulted in an upregulation of CYP19A1's promoter II activity and that this may be due 
to the direct interaction of the p65 subunit of $\mathrm{NF} \kappa \mathrm{B}$ with the CYP19A1 promoter as identified by chromatin immunoprecipitation (Fan et al. 2005). In addition, peroxisome proliferator-activated receptor- $\gamma$ and retinoid $\mathrm{X}$ receptor were speculated of downregulating aromatase expression, when stimulated simultaneously by disrupting the p65-promoter interaction (Mu et al. 2001, Fan et al. 2005). Considering that the regulation of CYP19A1, transcript levels of which are high in equine preovulatory follicles at $0 \mathrm{~h}$ and drop dramatically after hCG (Boerboom et al. 1999), is identical to the regulation observed for $17 \beta \mathrm{HSD} 1$, further studies will be needed to unravel whether similar or distinct transcriptional mechanisms are involved.

The $17 \beta$ HSD 1 cDNA has previously been cloned in various species, including human (Peltoketo et al. 1988), rat (Ghersevich et al. 1994), and mouse (Nokelainen et al. 1996). This study presents the equine cDNA and gene structure. Its genomic structure is consistent with that of other species, as they all have been demonstrated to have six exons and five introns. A pseudogene present upstream of the $17 \beta H S D 1$ gene has been identified in humans, orang utan, chimpanzees, and gibbons; however, it is not conserved in all species (Keller et al. 2005). It will be interesting to determine if this is also the case in horses. In addition, the sizes of introns 3 and 4 vary slightly between species and the $3^{\prime}$ end of exon 6 has been shown to exhibit considerable variability from one species to the next (Keller et al. 2005), as is the case in the mare. This variability is discernable when examining the amino acid sequence of the carboxy terminus and the length of the $17 \beta H S D 1$ proteins. A putative TATAbox motif was identified approximately $30 \mathrm{bp}$ upstream of the transcription start site of the equine gene. An initiator $(\mathrm{Inr})$ sequence $\left((\mathrm{C} / \mathrm{T})_{2}-\mathrm{C}-\mathrm{A}-(\mathrm{C} / \mathrm{T})_{5}\right)$, located at the transcription start site, also appears to be present (Lewin 2000). Notwithstanding, these sequences are not exact matches to traditional TATA and Inr sequences, and their relevance in transcriptional activation remains to be elucidated.

This study also investigates the expression of $17 \beta \mathrm{HSD} 1$ mRNA in equine tissues and establishes high levels of $17 \beta \mathrm{HSD} 1$ transcript in preovulatory follicles prior to $\mathrm{hCG}$. While high levels of equine $17 \beta \mathrm{HSD} 1 \mathrm{mRNA}$ were also observed in a placenta sample, which is consistent with the high 17ßHSD1 mRNA and protein observed in placentae of humans and non-human primates (Lin et al. 1992, Castagnetta et al. 1997, Schwabe et al. 2001), this is not the case for rodents, however (Akinola et al. 1997). It has also been detected by in situ hybridization in mice in granulosa cells of growing follicles, the intermediate lobe melanotrophs of the pituitary, in epithelial cells of the prostate, and in germ cells of the testis (Pelletier et al. 2004). It is further found in the epithelium of normal and cancerous breast tissue of women by in situ hybridization (Soderqvist et al. 1998, Miettinen et al. 1999, Oduwole et al. 2004).
In summary, this study is the first to characterize the primary structure of the equine $17 \beta \mathrm{HSD} 1 \mathrm{cDNA}$ and gene, to demonstrate the regulation of this gene during follicular luteinization in a monoovulatory species, to identify the preovulatory gonadotropin signal as a negative regulator of equine $17 \beta \mathrm{HSD} 1 \mathrm{mRNA}$ expression, and to propose $\mathrm{NF} \kappa \mathrm{B}$ and SF-1 as putative cis-acting elements in $17 \beta \mathrm{HSD} 1$ promoter activation. Considering the estrogen-activating activity of $17 \beta \mathrm{HSD} 1$, its gonadotropin-dependent downregulation provides an additional molecular basis for the decrease in $17 \beta$-estradiol biosynthetic capacity observed during the process of ovulation/luteinization.

\section{Funding}

This work was supported by Natural Sciences and Engineering Research Council of Canada (NSERC) Grant OPG0171135 (to J S), and a Canadian Institutes of Health investigator award (to J S), as well as a NSERC Postgraduate Scholarship (to K A B). The 17ßHSD1 genomic and cDNA nucleotide sequences reported in this paper have been submitted to GenBank with Accession numbers DQ418450 and DQ418451 respectively. The authors declare that there is no conflict of interest that would prejudice the impartiality of this research.

\section{References}

Adamski J \& Jakob FJ 2001 A guide to 17beta-hydroxysteroid dehydrogenases. Molecular and Cellular Endocrinology 171 1-4.

Akinola LA, Poutanen M, Vihko R \& Vihko P 1997 Expression of 17beta-hydroxysteroid dehydrogenase type 1 and type 2, P450 aromatase, and 20alpha-hydroxysteroid dehydrogenase enzymes in immature, mature, and pregnant rats. Endocrinology 138 2886-2892.

Baker ME 2001 Evolution of 17beta-hydroxysteroid dehydrogenases and their role in androgen, estrogen and retinoid action. Molecular and Cellular Endocrinology 171 211-215.

Boerboom D, Kerban A \& Sirois J 1999 Dual regulation of promoter IIand promoter 1f-derived cytochrome $\mathrm{P} 450$ aromatase transcripts in equine granulosa cells during human chorionic gonadotropininduced ovulation: a novel model for the study of aromatase promoter switching. Endocrinology $1404133-4141$.

Boerboom D, Pilon N, Behdjani R, Silversides DW \& Sirois J 2000 Expression and regulation of transcripts encoding two members of the NR5A nuclear receptor subfamily of orphan nuclear receptors, steroidogenic factor-1 and NR5A2, in equine ovarian cells during the ovulatory process. Endocrinology $1414647-4656$.

Bradford MM 1976 A rapid and sensitive method for the quantitation of microgram quantities of protein utilizing the principle of protein-dye binding. Analytical Biochemistry 72 248-254.

Brown KA, Boerboom D, Bouchard N, Dore M, Lussier JG \& Sirois J 2004 Human chorionic gonadotropin-dependent regulation of 17 beta-hydroxysteroid dehydrogenase type 4 in preovulatory follicles and its potential role in follicular luteinization. Endocrinology 145 1906-1915. 
Castagnetta LA, Carruba G, Traina A, Granata OM, Markus M, PavoneMacaluso M, Blomquist CH \& Adamski J 1997 Expression of different 17beta-hydroxysteroid dehydrogenase types and their activities in human prostate cancer cells. Endocrinology 138 4876-4882.

Dumont M, Luu-The V, de Launoit Y \& Labrie F 1992 Expression of human 17 beta-hydroxysteroid dehydrogenase in mammalian cells. Journal of Steroid Biochemistry and Molecular Biology 41 605-608.

Fan W, Yanase T, Morinaga H, Mu YM, Nomura M, Okabe T, Goto K, Harada N \& Nawata H 2005 Activation of peroxisome proliferatoractivated receptor-gamma and retinoid $\mathrm{X}$ receptor inhibits aromatase transcription via nuclear factor-kappaB. Endocrinology 146 85-92.

Filion F, Bouchard N, Goff AK, Lussier JG \& Sirois J 2001 Molecular cloning and induction of bovine prostaglandin $\mathrm{E}$ synthase by gonadotropins in ovarian follicles prior to ovulation in vivo. Journal of Biological Chemistry 276 34323-34330.

Fortune JE 1994 Ovarian follicular growth and development in mammals. Biology of Reproduction 50 225-232.

Ghersevich S, Nokelainen P, Poutanen M, Orava M, Autio-Harmainen H, Rajaniem H \& Vihko R 1994 Rat 17 beta-hydroxysteroid dehydrogenase type 1: primary structure and regulation of enzyme expression in rat ovary by diethylstilbestrol and gonadotropins in vivo. Endocrinology 135 1477-1487.

Ghersevich S, Akinola L, Kaminski T, Poutanen M, Isomaa V, Vihko R \& Vihko P 2000 Activin-A, but not inhibin, regulates 17betahydroxysteroid dehydrogenase type 1 activity and expression in cultured rat granulosa cells. Journal of Steroid Biochemistry and Molecular Biology 73 203-210.

Keller B, Ohnesorg T, Mindnich R, Gloeckner CJ, Breitling R, Scharfe M, Moeller G, Blocker H \& Adamski J 2005 Interspecies comparison of gene structure and computational analysis of gene regulation of 17beta-hydroxysteroid dehydrogenase type 1. Molecular and Cellular Endocrinology 248 168-171.

Lewin B 2000 The basal apparatus consists of RNA polymerase II and general factors. Genes VII, pp 627-632. New York: Oxford University Press Inc.

Lin SX, Yang F, Jin JZ, Breton R, Zhu DW, Luu-The V \& Labrie F 1992 Subunit identity of the dimeric 17 beta-hydroxysteroid dehydrogenase from human placenta. Journal of Biological Chemistry $\mathbf{2 6 7}$ $16182-16187$

Liu Z \& Simpson ER 1997 Steroidogenic factor 1 (SF-1) and SP1 are required for regulation of bovine $C Y P 11 A$ gene expression in bovine luteal cells and adrenal Y1 cells. Molecular Endocrinology 11 127-137.

Liu J, Antaya M, Boerboom D, Lussier JG, Silversides DW \& Sirois J 1999 The delayed activation of the prostaglandin $\mathrm{G} / \mathrm{H}$ synthase-2 promoter in bovine granulosa cells is associated with downregulation of truncated upstream stimulatory factor-2. Journal of Biological Chemistry 274 35037-35045.

Luu-The V 2001 Analysis and characteristics of multiple types of human 17beta-hydroxysteroid dehydrogenase. Journal of Steroid Biochemistry and Molecular Biology 76 143-151.

Luu The V, Labrie C, Zhao HF, Couet J, Lachance Y, Simard J, Leblanc G, Cote J, Berube D, Gagne R et al. 1989 Characterization of cDNAs for human estradiol 17 beta-dehydrogenase and assignment of the gene to chromosome 17: evidence of two mRNA species with distinct $5^{\prime}$ termini in human placenta. Molecular Endocrinology 3 1301-1309.

Luu-The V, Tremblay P \& Labrie F 2005 Characterization of type 12 $17 \beta$-hydroxysteroid dehydrogenase (17 $\beta$-HSD12), an isoform of type $317 \beta$-hydroxysteroid dehydrogenase responsible for estradiol formation in women. Molecular Endocrinology 20 437-443.

Miettinen M, Mustonen M, Poutanen M, Isomaa V, Wickman M, Soderqvist G, Vihko R \& Vihko P 1999 17Beta-hydroxysteroid dehydrogenases in normal human mammary epithelial cells and breast tissue. Breast Cancer Research and Treatment 57 175-182.

Mu YM, Yanase T, Nishi Y, Takayanagi R, Goto K \& Nawata H 2001 Combined treatment with specific ligands for PPARgamma:RXR nuclear receptor system markedly inhibits the expression of cytochrome P450arom in human granulosa cancer cells. Molecular and Cellular Endocrinology 181 239-248.

Murphy BD 2000 Models of luteinization. Biology of Reproduction 63 2-11.

Mustonen MV, Poutanen MH, Isomaa VV, Vihko PT \& Vihko RK 1997 Cloning of mouse 17beta-hydroxysteroid dehydrogenase type 2, and analysing expression of the mRNAs for types 1, 2, 3, 4 and 5 in mouse embryos and adult tissues. Biochemical Journal 325 199-205.

Nelson VL, Qin Kn KN, Rosenfield RL, Wood JR, Penning TM, Legro RS, Strauss JF, III. \& McAllister JM 2001 The biochemical basis for increased testosterone production in theca cells propagated from patients with polycystic ovary syndrome. Journal of Clinical Endocrinology and Metabolism 86 5925-5933.

Nokelainen P, Puranen T, Peltoketo H, Orava M, Vihko P \& Vihko R 1996 Molecular cloning of mouse 17 beta-hydroxysteroid dehydrogenase type 1 and characterization of enzyme activity. European Journal of Biochemistry 236 482-490.

Oduwole OO, Li Y, Isomaa VV, Mantyniemi A, Pulkka AE, Soini Y \& Vihko PT 2004 17Beta-hydroxysteroid dehydrogenase type 1 is an independent prognostic marker in breast cancer. Cancer Research 64 7604-7609.

Pelletier G, Luu-The V, Li S, Ren L \& Labrie F 2004 Localization of 17beta-hydroxysteroid dehydrogenase type $1 \mathrm{mRNA}$ in mouse tissues. Journal of Molecular Endocrinology 33 459-465.

Peltoketo H, Isomaa V, Maentausta O \& Vihko R 1988 Complete amino acid sequence of human placental 17 beta-hydroxysteroid dehydrogenase deduced from cDNA. FEBS Letters 239 73-77.

Peltoketo H, Luu-The V, Simard J \& Adamski J 1999 17betahydroxysteroid dehydrogenase (HSD)/17-ketosteroid reductase (KSR) family; nomenclature and main characteristics of the 17HSD/KSR enzymes. Journal of Molecular Endocrinology 23 1-11.

Penning TM 1997 Molecular endocrinology of hydroxysteroid dehydrogenases. Endocrine Reviews 18 281-305.

Piao YS, Peltoketo H, Jouppila A \& Vihko R 1997 Retinoic acids increase 17 beta-hydroxysteroid dehydrogenase type 1 expression in JEG-3 and T47D cells, but the stimulation is potentiated by epidermal growth factor, 12-O-tetradecanoylphorbol-13-acetate, and cyclic adenosine $3^{\prime}, 5^{\prime}$-monophosphate only in JEG-3 cells. Endocrinology 138 898-904.

Richards JS 1994 Hormonal control of gene expression in the ovary. Endocrine Reviews 15 725-751.

Ronen-Fuhrmann T, Timberg R, King SR, Hales KH, Hales DB, Stocco DM \& Orly J 1998 Spatio-temporal expression patterns of steroidogenic acute regulatory protein (StAR) during follicular development in the rat ovary. Endocrinology 139 303-315.

Sandhoff TW, Hales DB, Hales KH \& McLean MP 1998 Transcriptional regulation of the rat steroidogenic acute regulatory protein gene by steroidogenic factor 1. Endocrinology 139 4820-4831.

Schwabe I, Husen B \& Einspanier A 2001 Expression of the estradiolsynthesizing 17beta-hydroxysteroid dehydrogenases type 1 and type 7 in the nonhuman primate Callithrix jacchus. Molecular and Cellular Endocrinology 171 187-192.

Sha JA, Dudley K, Rajapaksha WR \& O'Shaughnessy PJ 1997 Sequence of mouse 17beta-hydroxysteroid dehydrogenase type 3 cDNA and tissue distribution of the type 1 and type 3 isoform mRNAs. Journal of Steroid Biochemistry and Molecular Biology 60 19-24.

Simpson ER, Misso M, Hewitt KN, Hill RA, Boon WC, Jones ME, Kovacic A, Zhou J \& Clyne CD 2005 Estrogen - the good, the bad, and the unexpected. Endocrine Reviews 26 322-330.

Sirois J \& Doré M 1997 The late induction of prostaglandin G/H synthase-2 in equine preovulatory follicles supports its role as a determinant of the ovulatory process. Endocrinology 138 4427-4434.

Sirois J, Kimmich TL \& Fortune JE 1991 Steroidogenesis by equine preovulatory follicles: relative roles of theca interna and granulosa cells. Endocrinology 128 1159-1166.

Sirois J, Levy LO, Simmons DL \& Richards JS 1993 Characterization and hormonal regulation of the promoter of the rat prostaglandin 
endoperoxide synthase 2 gene in granulosa cells. Identification of functional and protein-binding regions. Journal of Biological Chemistry 268 12199-12206.

Soderqvist G, Poutanen M, Wickman M, von Schoultz B, Skoog L \& Vihko R 1998 17Beta-hydroxysteroid dehydrogenase type 1 in normal breast tissue during the menstrual cycle and hormonal contraception. Journal of Clinical Endocrinology and Metabolism 83 $1190-1193$.

Vaskivuo TE, Ottander U, Oduwole O, Isomaa V, Vihko P, Olofsson JI \& Tapanainen JS 2002 Role of apoptosis, apoptosis-related factors and 17beta-hydroxysteroid dehydrogenases in human corpus luteum regression. Molecular and Cellular Endocrinology 194 191-200.
Zeleznik ABD 1994 Control of follicular development, corpus luteum function and recognition of pregnancy in higher primates. Physiology of Reproduction, pp 751-782. New York: Raven Press.

Zhu SJ, Li Y, Li H, Wang YL, Xiao ZJ, Vihko P \& Piao YS 2002 Retinoic acids promote the action of aromatase and 17beta-hydroxysteroid dehydrogenase type 1 on the biosynthesis of 17 beta-estradiol in placental cells. Journal of Endocrinology 172 31-43.

Received 18 August 2006

Accepted 29 September 2006 